\title{
The relationship marketing practices of travel agencies in the Western Cape Province
}

\author{
M. Roberts-Lombard* \\ Department of Marketing Management \\ University of Johannesburg, Johannesburg 2006, Republic of South Africa \\ mornayrl@uj.ac.za \\ T.F.J. Steyn \\ School of Business, Cameron University, \\ Oklahoma State, USA,
}

Received September 2008

\begin{abstract}
Relationship marketing has received much attention and widespread publicity over the past ten years and has moved to the forefront of research and practice. It provides organizations with a management tool to establish economically profitable relationships, networks and interactions with different, but equally important stakeholder markets. The purpose of the article is to research the relationship marketing practices of travel agencies in the Western Cape province. The empirical research component of the study consisted of the completion of structured questionnaires through personal interviews. The questionnaire consisted of a structured format and incorporated two types of questions, namely closedended questions and five point Likert-type statements. The findings of the study concluded that the relationships between travel agencies and the different role players in their market environment are fragmented. The direct marketing initiatives of SAA and hotel groups such as the Southern Sun and Protea hotels are putting strain on the current relationship between travel agencies and these suppliers. The managerial implications for the study specify that an environment must be created which is more accessible to the critical interaction between the travel agency in the Western Cape province and its different role players. This is especially relevant considering that organisations are continuously becoming more aware that their success within a highly competitive market environment depends on the building of long term relationships with each of these role players.
\end{abstract}

*To whom all correspondence should be addressed.

\section{Introduction}

Relationships are the basis on which trade in the travel industry is built (Grönroos, 2000:55). The establishment and management of these relationships must be to the advantage of all parties in the relationship (Swart, 2003:120). Steyn, Ellis and Musika (2004:35-36) refers to relationship marketing as a consumer centered approach seeking long term relationships with existing as well as with prospective partners to the marketing process i.e., suppliers, alliances, competitors, distributors, employees and consumers. Relationship marketing wants to establish a long term relationship with customers of the organisation as well as other role players which will contribute to the successful operation of the organisation in the future (Eiriz \& Wilson, 2006:275-276).

The term "other role players" refers to the government, professional associations, suppliers and the employees of the organisation. All these role players need to work together to ensure the satisfaction of customer needs. This can be done by providing customers with quality products and service delivery. Quality products and services are important to ensure both the future survival of the organisation and to protect its competitive position in the market (Cant, 2000:16).

This article will attempt to provide a relationship marketing framework for travel agencies in the Western Cape province, indicate what the current status is of the relationships which travel agencies in the province have with different markets and interest groups and will provide recommendations to the management of travel agencies in the Western Cape province regarding the improved application of the principles of relationship marketing in their businesses.

\section{Problem statement}

Relationship marketing emphasise the creation and establishment of long term relationships with different markets of the organisation. These markets encompass suppler markets, customer markets, reference markets, recruitment markets, internal markets and influence markets. Organisations are continuously becoming more aware that their success within a highly competitive market environment depends on the building of long term relationships with each of these markets. These long term relationships are not independent of each other. It constitutes 
a network of relationships which directly influence the value added components of the organisations' products and services to customers. In addition, it further influences the competitive position of the organisation within the market environment (Payne, Ballantyne \& Christopher, 2005:855871).

However, Townes (2007), in a personal interview with the author, indicated that the relationships between travel agencies and role players in the marketing environment are fragmented. The direct marketing initiatives of SAA and hotel groups such as the Southern Sun and Protea hotels are putting strain on the current relationship between travel agencies and these suppliers. There is also a lack of trust in the relationship between travel agencies and the Avis car rental group since the latter is approaching corporate customers directly to secure a sale.

Furthermore, the management of travel agencies in the Western Cape province do not research the needs and wants of their customers on a continuous basis to determine their preferences with regard to the supply of products and services. It therefore becomes increasingly difficult for travel agencies to satisfy the needs and wants of both their corporate and leisure customers.

There is currently also no formal network of positive referrals initiated by travel agencies in the Western Cape province. The large staff turnover in the travel agency industry is the result of poor salaries, a lack of educational sponsorships and poor management relationships with employees working for travel agencies. The internal needs of employees also need to be addressed in a more professional manner to increase their current motivational level. Finally, the management of travel agencies in the Western Cape province have a strong relationship with ASATA. However, it is necessary that the different members need to build stronger relationships amongst themselves to influence the management of ASATA regarding issues of common concern (Townes, 2007).

Against this background there is a clear need for the management of travel agencies in the Western Cape province to apply the principles of relationship marketing to their daily operations. It is furthermore important that travel agencies also apply these principles to their relationship building initiatives with the various stakeholders that influence their competitiveness in the market.

\section{Purpose of the article}

The purpose of the article is to research the relationship marketing practices of travel agencies in the Western Cape province. The article wants to establish the current level of relationship marketing in the travel agency industry in the province and to identify limitations in relationship marketing relationships which might exist in the industry. The principles of relationship marketing in a number of markets (e.g. supplier, customer, referral, recruitment, internal and influence markets) are identified and the application thereof by the travel agency industry in the Western Cape province determined.

\section{Objectives of the article}

The purpose of the article is supported by the following objectives:

- To focus on investigating travel agencies in the Western Cape province's supplier market, customer market, referral market, recruitment market, internal market and influence market relationships; and

- Making recommendations to travel agencies in the Western Cape province regarding the improved application of the principles of relationship marketing.

\section{Theoretical overview}

To achieve success in the complex and fast-paced market place of today, it is increasingly being acknowledged that a number of key market areas need to be addressed. The Relationship Marketing Multiple Markets Model enables a diagnostic review to be undertaken of the key market domains that may be of importance to any given organisation (Harwood, Garry \& Broderick, 2008:26-37). As a result of such a diagnosis, a number of key groups are identified which are of special importance. The exact number of markets to be focused on by any given organisation will vary. Thus some organisations will need to focus significant emphasis on relatively few, while others will have a much greater number to take into account. Each of the markets of the relationship Marketing (RM) multiple markets model will be discussed in more detail below.

\section{Supplier markets}

The creation and establishment of value-adding, long term relationships with suppliers is necessary for the future existence of an organisation. Such a relationship must be based on the principles of co-operation, trust and commitment. Customer organisations and their suppliers also focus on the establishment of a relationship which is mutually beneficial, mutually inter-dependent and characterised by two way communication between the parties (Ndubisi, 2007:99-100). The suppliers of services and products to the firm are increasingly being viewed as collaborators in the value chain rather than adversaries from whom the best practice can be extracted (Harwood et al., 2008:37). The following factors are important for the customer organisation when creating and establishing a long term relationship with suppliers, namely the reliability of the agreement with suppliers, the willingness of the supplier to deliver products and services on time and the ability of the supplier to be flexible with deliveries (Parvatiyar \& Sheth, 2000:9-12).

\section{Customer markets}

The products and/or services of an organisation is an integrated part of its ability to satisfy the needs and wants of customers. It encompass a combination of the development and characteristics of a product through the delivery of a quality service. By delivering a quality service, an organisation attempt to satisfy the needs of customers with greater success than competitors (Jordaan \& Prinsloo, 
2004:81). The customers of the organisation can become either final consumers or intermediaries between the organisation and its consumers. It is the external customers of the organisation that eventually becomes the final consumers of the organisations products or services. Within customer markets, the customer must develop a commitment to a relationship with the organisation (Otto, 2004:13). Ward and Dagger (2005:283) stipulate that in any form of relationship between the customer and the service provider the attitude of the customer towards such a relationship is likely to be of importance, thus the stronger the customer perceives the importance of relationships in general, the more likely the customer is to develop a stronger relationship with the service provider. While there are many potential dimensions to such a relationship, the importance of these dimensions to customers may impact on the strength of the relationship developed between the service provider and customer. Developing, maintaining and strengthening a relationship will depend on the customer's perception of the importance of key relationship dimensions, namely bonding, empathy, reciprocity, trust, friendship, recognition, thoughtfulness, understanding, time to listen, commitment, loyalty, and shared values. The perceptions of the importance of these relationship dimensions will therefore impact on relationship strength.

\section{Reference markets}

What a marketer understands from word-of-mouth is that which individuals are communicating about an organisation in their daily life. Word-of-mouth can have a direct influence on the future existence of an organisation since it implies positive or negative communication regarding the products and services of the organisation and is communicated from one person to another. The attractiveness of word-of-mouth is that it is based on one persons respect for the judgement of another person (Leverin \& Liljander, 2006: 233-237; Hendriks, 1998:54). George (2006:357) also stipulate that referrals are intermediaries who influence an organisation's performance. The intermediaries would not send consumers to an organization with a bad reputation, so this market can be especially detrimental since word-of-mouth recommendations strongly influence consumer buying behaviour. Referrals may come from friends or family, satisfied consumers, sales representatives and travel agents. Customers depend on word-of-mouth to limit the uncertainty which is associated with the purchasing of products and services (Jordaan \& Prinsloo, 2004:328-9).

\section{Recruitment markets}

An organisation consists of different resources of which the most important is human resources (Flood \& Gibson, 2002:1). The successful survival of an organisation depends on its ability to recruit the most qualified and skilled employees. Organisations must further ensure that within a highly mobile labour market environment it retains employees to secure its competitiveness and future success. This requires a comprehensive human resources planning process which will provide an organisation with a competitive advantage above other organisations (Schultz, 2001:218-219). Mostert and Rathbone (2007:36) argue that organizations whose employees are dissatisfied with their jobs, who are not committed to the organisation and who are continuously absent from work in an attempt to recover from extremely high jobs demands, will certainly experience severe financial constraints. Therefore, management should not restrict its focus exclusively to aspects such as financial profit, productivity, and the management of employees, but should also focus on enhancing those aspects of the job that would result in its employees feeling energetic, dedicated, and engaged in their work.

\section{Internal markets}

Internal marketing is a management philosophy that focus on the satisfaction of internal customers as a pre-requisite for external customer satisfaction. Internal marketing theories state that the organisation emphasise the importance in employee need satisfaction and approaches jobs as internal products, aimed towards the development and motivation of best-qualified personnel (Zampetaki \& Moustakis, 2007:417). The basic premise on which internal marketing initiatives are built is that the building of good relationships with employees will have a direct influence on the relationship between employees and the external customers of the business (Otto, 2004:34). Internal marketing initiated from the services marketing literature and is focused on applying the traditional principles of marketing to the employees of a business (Herington, Johnson \& Scott, 2006:369-370).

\section{Influence markets}

The process of influence marketing occurs through communication between the organisation and external stakeholders. It encompass the identification of influencers as well as the creation of a positive image of the organisations products and services amongst these groups (Wiehahn, 2001:2; Kotler \& Armstrong, 2004:516-518). Influence marketing empowers the organisation to communicate with external stakeholders to create and establish a positive relationship with these groups (Lamb, Hair, McDaniel, Boshoff, \& Terblanche, 2004:321). Influence markets include financial and regulatory organisations and the government. These may include communication systems, transport infrastructure, defense and energy-related projects (Harwood et al., 2008:37).

\section{Methodology}

\section{Population}

The population for this study included all the travel agents registered with the Association of South African Travel Agents (ASATA) in the Western Cape province. ASATA is the professional body that represents the interests of travel agents in the country. The target population for this study was 118 travel agencies of which 61 participated in the completion of questionnaires. In terms of the small size of the population, it was decided to conduct a census. A census is a count of all the elements in a population (Tustin, Lighthelm, Martins \& van Wyk, 2005:337). A response rate of $53 \%$ was obtained for this study $(n=61)$. 


\section{Research instrument}

The measuring instrument used was a structured questionnaire which included some adapted items from previously tested measuring instruments, for example, the Relationship Marketing instrument from Steyn (2000:296). Personal interviews were conducted with the owners or managers of travel agencies in the Western Cape. The empirical research component of the study consisted of the completion of structured questionnaires through personal interviews. The questionnaire consisted of two sections. Section A incorporated closed-ended questions to gather demographic data on the profile of the travel agency. The biographical data of the respondents was gathered through two questions in this section, namely the location and the target market of the travel agency.

Section B was in the format of a five-point Likert-type scale, comprising three sub-sections. The first sub-section included 26 statements on the recruitment market, the second subsection encompassed 32 statements on the internal market and the third sub-section included 23 statements on the influence market of travel agencies in the Western Cape. The purpose of these statements were to test respondents' current and ideal application of identified relationship marketing principles in the recruitment market, internal market and influence market of travel agencies in the Western Cape. The statement's response continuum ranged from $1-5$, where $1=$ strongly disagree; $2=$ disagree; $3=$ neutral; $4=$ agree and $5=$ strongly agree.

Structured interviews were conducted with seven owners or managers of travel agencies to pre-test the questionnaire before its formal application as a data gathering instrument.

\section{Data gathering}

Personal interviews were conducted with the managers and/or owners of travel agencies in the Western Cape province. A time frame of forty five days was used to complete the interviews. To ensure the participation of the maximum number of population elements, interviews were arranged on the premises of the travel agency.

\section{Data analysis}

The statistical software package SAS System for Windows Release, 2002-2005: Version 9.1 Edition; SAS OnlineDoc, 2005: Version 9.1 was used for the analysis of the gathered data. The following three phase analysis was done:

- Averages of the differences between the ideal and the current application of internal marketing practices by travel agencies in the Western Cape province were calculated;

- Standard deviations for individual items on the questionnaire were calculated;

- Explorative factor analysis (EFA) to determine the validity of the questionnaire as a measuring instrument. Maximum likelihood was used as the method of factor extraction, and a direct quartimin oblique rotation was specified. According to the MINEIGEN criterion one factor was retained for each identified sub-construct. The research instrument can therefore be regarded as a valid research instrument.

- Cronbach's Alpha-values to determine the reliability of the questionnaire as a measurement instrument. The calculation of Cronbach's Alpha-values was done for each sub-construct. Hocking, Stacks and McDermott (2003:131) indicate that Cronbach's Alpha-values determine the consistency according to which respondents answered the different items on the questionnaire. Nunnally and Bernstein (1994:264-265) recommend Cronbach Alpha coefficient scores above a 0.7 cut-off value. Table 1 below illustrate that all the sub-constructs were measured with scales that could be described as reliable.

- Practical significance by means of effect sizes. Cohen's d-values were used for this purpose. This study did not make use of inferential statistics (pvalues), but applied the d-values of Cohen to calculate effect sizes. The effect sizes indicate the practically significant differences between the current application of the items in the questionnaire and what the ideal application of the items should be (Ellis \& Steyn, 2003:51-53). A small (practically insignificant) effect size requires no improvement on the aspect addressed. However, a medium or large effect size (practically significant) implies that more emphasis should be placed on the aspect discussed to ensure improvement. Effect sizes (d-values) were calculated by using the following formula (Cohen, 1988: 20-27):

$$
\mathrm{d}=\frac{\left|\overline{\mathrm{x}}_{1}-\overline{\mathrm{x}}_{2}\right|}{\mathrm{s}_{\max }}
$$

where:

- $\quad \mathrm{d}=$ the effect size;

- $\overline{\mathrm{x}}_{1}-\overline{\mathrm{x}}_{2}$ is the difference between the current situation (a-value) and the ideal situation (b-value) (e.g. respondents had to indicate on a Likert scale of $1-5$ how they currently experience a specific scenario, through a statement on the questionnaire, and how they want to experience it as an ideal scenario); and

- $\mathrm{s}_{\max }$ is the maximum standard deviation of the two comparable groups.

Ellis \& Steyn (2003:52) and Steyn (1999:3) specify below the cut off points which can be used when interpreting effect sizes:

- $\quad$ If $\mathrm{d} \approx 0,2$, it indicates a small effect;

- If $\mathrm{d} \approx 0,5$, it indicates a medium effect; and

- If $\mathrm{d} \approx 0,8$ or is larger, the effect is both large and practically significant. 
Table 1: Cronbach's Alpha-values for the various relationship marketing constructs in the study

\begin{tabular}{|c|c|c|c|}
\hline CONSTRUCT & SUB CONSTRUCT & $\mathbf{N}$ & $\begin{array}{l}\text { CRONBACH'S ALPHA } \\
\text { CO-EFFICIENT }\end{array}$ \\
\hline \multirow[t]{4}{*}{ Supplier markets } & Value adding components & 61 & 0.88 \\
\hline & Longterm relationship inclination & 61 & 0,83 \\
\hline & Strengthening the relationship with suppliers & 61 & 0,75 \\
\hline & Viability of establishing relationships with suppliers & 61 & 0,75 \\
\hline \multirow[t]{3}{*}{ Customer markets } & $\begin{array}{l}\text { Components for the building of long term relationships with } \\
\text { customers }\end{array}$ & 61 & 0,91 \\
\hline & Customer loyalty and commitment & 61 & 0,90 \\
\hline & Customer research for the satisfaction of customer needs & 61 & 0,90 \\
\hline \multirow[t]{3}{*}{ Reference markets } & Requirements for positive word-of-mouth marketing & 61 & 0,84 \\
\hline & Reference groups as a marketing instrument & 61 & 0,68 \\
\hline & Mechanisms to ensure customer referrals & 61 & 0,82 \\
\hline \multirow[t]{6}{*}{ Recruitment markets } & Candidate characteristics & 61 & 0,84 \\
\hline & Manpower needs assessment & 61 & 0,81 \\
\hline & Recruitment policy & 61 & 0,74 \\
\hline & Candidate requirements & 61 & 0,82 \\
\hline & Post description & 61 & 0,88 \\
\hline & Company offer & 61 & 0,86 \\
\hline \multirow[t]{6}{*}{ Internal markets } & Internal marketing environment & 61 & 0,94 \\
\hline & Attitude of employees towards internal marketing & 61 & 0,89 \\
\hline & Motivation of employees & 61 & 0,91 \\
\hline & Building blocks for internal marketing & 61 & 0,90 \\
\hline & Internal marketing research areas & 61 & 0,93 \\
\hline & Implementation of internal marketing activities & 61 & 0,88 \\
\hline \multirow[t]{7}{*}{ Influence markets } & Focus of influence marketing activities & 61 & 0,94 \\
\hline & Influencing of the influence marketing environment & 61 & 0,85 \\
\hline & Approach to influencers & 61 & 0,82 \\
\hline & Reasons for the application of influence marketing activities & 61 & 0,89 \\
\hline & $\begin{array}{l}\text { Important components before the application of influence marketing } \\
\text { activities }\end{array}$ & 61 & 0,94 \\
\hline & Lobbying activities & 61 & 0,44 \\
\hline & Ground principles when applying influence marketing principles & 61 & 0,86 \\
\hline
\end{tabular}

From Table 2 below it can be deduced that the research instrument was reliable.

The major findings of the study are discussed in the section to follow.

\section{Major findings}

It becomes increasingly important for travel agencies to build long term relationships with the different role players that influence their daily operations. The major findings of the study is listed below and is discussed according to the different markets which is characteristic of the travel agency industry in the Western Cape province.

\section{Supplier markets}

\section{- $\quad$ Value adding components}

The owners and managers of travel agencies $(n=61)$ view their current application of the components which add value to their relationships with suppliers as good $[x(a)=4.14]$. However, these owners or managers view the ideal application of these components higher $[x(b)=4.56]$. The medium effect size $(d=0,68)$ illustrate that the owners and managers of travel agencies would prefer that the components which add value to their relationships with suppliers be better implemented.

\section{- $\quad$ Long term relationship inclination}

The owners and managers of travel agencies $(n=61)$ indicated a long term inclination towards establishing a relationship with their suppliers $[x(a)=4,27]$. These owners or managers are, however, of the opinion that the long term nature of their relationship building inclination can be further developed $[x(b)=4,59]$. The medium effect size $(d=$ $0,54)$ illustrate that the owners and managers of travel agencies would prefer to develop their long term relationship building inclination towards suppliers further. 
Table 2: Current situation $[x(a)]$ Ideal situation $[x(b)] b$ and Effect size (d) values for the various relationship marketing constructs in the study

\begin{tabular}{l|c|c|c|c|c}
\hline \multicolumn{1}{c|}{ Supplier market as a relationship marketing construct } \\
\hline Sub-construct & $\mathbf{n}$ & $\begin{array}{c}\text { Average } \\
\mathbf{( a )} \\
{[\boldsymbol{x}(\mathbf{a}) \mathbf{n}}\end{array}$ & $\begin{array}{c}\text { Average } \\
\mathbf{( b )} \\
{[\boldsymbol{x}(\mathbf{b})]}\end{array}$ & $\begin{array}{c}\text { Maximum standard } \\
\text { deviation }\end{array}$ & $\begin{array}{c}\text { Effect size } \\
\mathbf{( d )}\end{array}$ \\
\hline Value adding components & 61 & 4,14 & 4,56 & 0,67 & 0,68 \\
\hline Longterm relationship inclination & 61 & 4,27 & 4,59 & 0,61 & 0,54 \\
\hline $\begin{array}{l}\text { Strengthening the relationship with } \\
\text { suppliers }\end{array}$ & 61 & 3,77 & 4,55 & 0,87 & 0,79 \\
\hline $\begin{array}{l}\text { Viability of establishing relationships } \\
\text { with suppliers }\end{array}$ & 61 & 4,09 & 4,38 & 0,82 & 0,51 \\
\hline
\end{tabular}
with suppliers

\section{Sub-construct}

\begin{tabular}{l|l|}
\hline \multicolumn{1}{|c|}{ Sub-construct } \\
\hline $\begin{array}{l}\text { Components for the building of long } \\
\text { term relationships with customers }\end{array}$ \\
\hline $\begin{array}{l}\text { Customer loyalty and commitment } \\
\text { Customer research for the satisfaction of } \\
\text { customer needs }\end{array}$ \\
\hline
\end{tabular}

Customer market as a relationship marketing construct

\begin{tabular}{|c|c|c|c|c}
$\mathbf{n}$ & $\begin{array}{c}\text { Average } \\
\mathbf{( a )} \\
{[\boldsymbol{x}(\mathbf{a})]}\end{array}$ & $\begin{array}{c}\text { Average } \\
\mathbf{( b )} \\
{[\boldsymbol{x}(\mathbf{b})]}\end{array}$ & $\begin{array}{c}\text { Maximum standard } \\
\text { deviation }\end{array}$ & $\begin{array}{c}\text { Effect size } \\
\mathbf{( d )}\end{array}$ \\
\hline 61 & 4,38 & 4,76 & 0,55 & 0,74 \\
\hline 61 & 4,67 & 4,82 & 0,41 & 0,43 \\
\hline 61 & 4,19 & 4,74 & 0,69 & 0,79 \\
\hline
\end{tabular}

Referral market as a relationship marketing construct

\begin{tabular}{|c|c|c|c|c|c|}
\hline Sub-construct & $\mathbf{n}$ & $\begin{array}{c}\text { Average } \\
\text { (a) } \\
{[x(a)]} \\
\end{array}$ & $\begin{array}{c}\text { Average } \\
\text { (b) } \\
{[x(b)]} \\
\end{array}$ & $\begin{array}{c}\text { Maximum standard } \\
\text { deviation }\end{array}$ & $\begin{array}{l}\text { Effect size } \\
\text { (d) }\end{array}$ \\
\hline $\begin{array}{l}\text { Requirements for positive word-of- } \\
\text { mouth marketing }\end{array}$ & 61 & 4,37 & 4,73 & 0,56 & 0,69 \\
\hline $\begin{array}{lllll}\begin{array}{l}\text { Reference } \\
\text { instrument }\end{array} & \text { groups as a marketing } \\
\end{array}$ & 61 & 3,47 & 4,19 & 0,80 & 1,01 \\
\hline \multicolumn{6}{|c|}{$\begin{array}{ll}\text { Recruitment market as a relationship marketing construct } \\
\end{array}$} \\
\hline Sub-construct & $\mathbf{n}$ & $\begin{array}{c}\text { Average } \\
\text { (a) } \\
{[x(\mathbf{a})]}\end{array}$ & $\begin{array}{c}\text { Average } \\
\text { (b) } \\
{[x(\mathbf{b})]}\end{array}$ & $\begin{array}{c}\text { Maximum standard } \\
\text { deviation }\end{array}$ & $\begin{array}{l}\text { Effect size } \\
\text { (d) }\end{array}$ \\
\hline Candidate characteristics & 61 & 4,35 & 4,61 & 0,61 & 0,52 \\
\hline Manpower needs assessment & 61 & 3,08 & 3,79 & 0,89 & 0,89 \\
\hline Recruitment policy & 61 & 3,35 & 3,67 & 1,05 & 0,52 \\
\hline Candidate requirements & 61 & 4,54 & 4,62 & 0,50 & 0,24 \\
\hline Post description & 61 & 4,39 & 4,59 & 0,57 & 0,43 \\
\hline Company offer & 61 & 3,90 & 4,20 & 0,82 & 0,53 \\
\hline
\end{tabular}

Internal market as a relationship marketing construct

\begin{tabular}{|c|c|c|c|c|c|}
\hline Sub-construct & $\mathbf{n}$ & $\begin{array}{c}\text { Average } \\
\text { (a) } \\
{[x(a)]} \\
\end{array}$ & $\begin{array}{c}\text { Average } \\
\text { (b) } \\
{[x(\mathbf{b})]} \\
\end{array}$ & $\begin{array}{c}\text { Maximum standard } \\
\text { deviation }\end{array}$ & $\begin{array}{l}\text { Effect size } \\
\text { (d) }\end{array}$ \\
\hline Internal marketing environment & 61 & 4,08 & 4,58 & 0,73 & 0,79 \\
\hline $\begin{array}{l}\text { Attitude of employees towards internal } \\
\text { marketing }\end{array}$ & 61 & 4,36 & 4,65 & 0,63 & 0,49 \\
\hline Motivation of employees & 61 & 3,80 & 4,49 & 0,89 & 0,85 \\
\hline Building blocks for internal marketing & 61 & 4,02 & 4,59 & 0,78 & 0,70 \\
\hline Internal marketing research areas & 61 & 3,91 & 4,49 & 0,91 & 0,74 \\
\hline $\begin{array}{l}\text { Implementation of internal marketing } \\
\text { activities }\end{array}$ & 61 & 3,99 & 4,51 & 0,75 & 0,80 \\
\hline \multicolumn{6}{|c|}{$\begin{array}{ll}\text { Influence market as a relationship marketing construct } \\
\end{array}$} \\
\hline Sub-construct & $\mathbf{n}$ & $\begin{array}{c}\text { Average } \\
\text { (a) } \\
{[x(a)]} \\
\end{array}$ & $\begin{array}{c}\text { Average } \\
\text { (b) } \\
{[x(b)]} \\
\end{array}$ & $\begin{array}{c}\text { Maximum standard } \\
\text { deviation }\end{array}$ & $\begin{array}{l}\text { Effect size } \\
\text { (d) }\end{array}$ \\
\hline Focus of influence marketing activities & 61 & 3,55 & 4,27 & 0,92 & 0,86 \\
\hline $\begin{array}{l}\text { Influencing of the influence marketing } \\
\text { environment }\end{array}$ & 61 & 4,19 & 4,59 & 0,80 & 0,54 \\
\hline Approach to influencers & 61 & 3,95 & 4,24 & 0,80 & 0,57 \\
\hline $\begin{array}{l}\text { Reasons for the application of influence } \\
\text { marketing activities }\end{array}$ & 61 & 3,40 & 4,12 & 1,00 & 0,73 \\
\hline $\begin{array}{l}\text { Important components before the } \\
\text { application of influence marketing } \\
\text { activities }\end{array}$ & 61 & 3,44 & 4,09 & 0,97 & 0,86 \\
\hline Lobbying activities & 61 & 4,12 & 4,36 & 0,71 & 0,56 \\
\hline
\end{tabular}




\section{- $\quad$ Strengthening of the relationship with suppliers}

The owners and managers of travel agencies $(n=61)$ indicated that their relationships with suppliers are strong and that suppliers are attempting to strengthen their relationships with travel agencies $[\mathrm{x}(\mathrm{a})=3,77]$. These owners or managers are, however, of the opinion that this relationship can, ideally, be further strengthened $[\mathrm{x}(\mathrm{b})=$ $4,55]$. The large effect size $(d=0,79)$ indicate that the owners and managers of travel agencies are of the opinion that the strengthening of the relationship between themselves and their suppliers must definitely be prioritised.

\section{- Viability of relationships with suppliers}

The owners and managers of travel agencies $(n=61)$ indicated that they are evaluating the viability of a relationship with their suppliers by focusing on specific factors $[x(a)=4.09]$. These owners or managers are, however, of the opinion that they must consider these factors more definitely $[x(b)=4.38]$. The medium effect size $(d=0,51)$ indicated that the owners and managers of travel agencies must provide a stronger focus on determining the viability of establishing a long term relationship with suppliers.

\section{Customer markets}

- Components for the building of long term relationships with customers

The owners and managers of travel agencies $(n=61)$ view the current application of the components which ensures a long term relationship with customers as good $[x(\mathrm{a})=4.38]$. However, these owners or managers view the ideal application of these components higher $[x(b)=4.76]$. The medium effect size $(d=0,74)$ indicate that the owners and managers of travel agencies would prefer that the components which ensures the building of long term relationships with customers be better implemented.

\section{- Customer loyalty and commitment}

The owners and managers of travel agencies $(n=61)$ indicate a long term commitment towards the retention of customers. This strengthens the commitment and loyalty of customers towards the travel agency $[x(a)=4.67]$. The owners and managers of travel agencies are, however, of the opinion that the long term nature of their relationship commitment towards customers can further be strengthened $[x(b)=4.82]$. The small effect size $(d=0,43)$ indicate that the owners and managers of travel agencies are of the opinion that their focus on the satisfaction of customer needs are satisfactory to ensure the commitment of loyalty of customers.

- Customer research for the satisfaction of customer needs The owners and managers of travel agencies $(n=61)$ indicate that the planning and implementation of research activities to determine the needs and satisfaction levels of customers are successfully applied in the travel agency $[x(\mathrm{a})=4.19]$. These owners or managers are, however, of the opinion that these research activities can be more structured to ensure the successful measurement of customers need satisfaction levels $[x(b)=4.74]$. The large effect size $(d=0,79)$ indicate that the owners and managers of travel agencies hold the view that the planning and implementation of research activities to determine the needs of customers, must be given priority.

\section{Referral markets}

- Requirements for positive word-of-mouth marketing

The owners and managers of travel agencies $(n=61)$ view their current ability to stimulate customers to perform positive word-of-mouth as good $[x(\mathrm{a})=4.37]$, but view the ideal application thereof as higher $[x(b)=4.73]$. The medium effect size $(d=0,69)$ indicate that the owners and managers of travel agencies would prefer that the requirements for positive word-of-mouth be better implemented.

\section{- Reference groups as a marketing instrument}

The owners and managers of travel agencies $(n=61)$ indicate that reference groups are used as a marketing instrument within the broader marketing strategy of the travel agency $[x(a)=3.47]$. The owners or managers hold the view that these reference groups could, ideally, be better used to perform positive word-of-mouth for the travel agency $[x(\mathrm{a})$ $=4.19]$. A large effect size $(\mathrm{d}=1,01)$ indicate that the owners and managers of travel agencies are of the opinion that the strengthening of the relationship between themselves and their reference groups to stimulate positive marketing, must be given priority.

\section{Recruitment markets}

\section{- Candidate characteristics}

The owners and managers of travel agencies $(n=61)$ view the recruitment of employees as an important function which can directly influence the future existence of the travel agency. These owners or managers view their focus on the different characteristics which a candidate must possess before an appointment is made, as good $[x(\mathrm{a})=$ 4.35]. However, the owners or managers want the ideal application thereof to be higher $[x(b)=4.61]$. The medium effect size $(d=0,52)$ illustrate that the owners and managers of travel agencies would prefer that more emphasis is placed on the characteristics which a candidate requires before an appointment is made.

\section{- Manpower needs assessment}

The owners and managers of travel agencies $(n=61)$ put a strong emphasis on determining their current human resources needs $[x(\mathrm{a})=3.08]$. These owners or managers are, however, of the opinion that this focus can, ideally, bed $[x(b)=3.79]$. The large effect size $(d=0,89)$ indicate that the owners and managers of travel agencies are of the opinion that the determination of human resources needs must be given priority.

\section{- Recruitment policy}

The owners and managers of travel agencies $(n=61)$ indicate that they make use of a structured recruitment policy when new candidates are appointed in vacant posts $[x(a)=3.35]$. These owners or managers are, however, of the opinion that a greater focus must be placed on the application of the components which constitutes the recruitment policy of the travel agency $[x(b)=3.67]$. The medium effect size $(d=0,52)$ indicate that the owners and managers of travel agencies are 
of the opinion that they must view the components of their recruitment policy when appointing new candidates in a stronger light.

\section{- Candidate requirements}

The owners and managers of travel agencies $(n=61)$ indicate that they put great emphasis on the individual skills of candidates before they are appointed in a vacant position $[x(\mathrm{a})=4.54]$. These owners or managers are, however, of the opinion that this focus can ideally be more strengthened $[x(b)=4.62]$. The small effect size $(d=0,24)$ indicate that the owners and managers of travel agencies do appoint candidates who possess the necessary skills required to operate as travel agents in the industry. As a result there is no practically significant room for improvement with regard to the item in the sub-construct.

\section{- Post description}

The owners and managers of travel agencies $(n=61)$ indicate that they compile a clear post description for a vacant position before a new candidate is recruited for such a position $[x(a)=4.39]$. These owners or managers are, however, of the opinion that their focus on this aspect can be further strengthened $[x(b)=4.59]$. The small effect size $(d=0,43)$ illustrate that the owners and managers of travel agencies are doing comprehensive planning before an appointment is made in a vacant position. There is no practically significant room for improvement with regard to the items as specified in this sub-construct since the potential candidates post description and responsibilities are specified before an interview is conducted with the potential candidate.

\section{Internal markets}

\section{- Internal marketing environment}

The owners and managers of travel agencies $(n=61)$ are of the opinion that their current application of the principles to create a positive internal marketing environment is good $[x(a)=4.08]$. However, they view the ideal application of these principles higher $[x(b)=4.58]$. The large effect size $(d=0,79)$ illustrate that the owners and managers of travel agencies in the Western Cape province perceive a practically significant difference between the current application of principles to establish a positive internal marketing environment in their businesses and the ideal application thereof.

\section{- Approach of employees towards internal marketing}

The owners and managers of travel agencies $(n=61)$ indicated that their current internal marketing initiatives are supported by their employees. The reason for this being that the owners and managers established a business culture which address the internal needs of employees $[x(a)=4,36]$. These owners or managers are, however, of the opinion that their focus on internal marketing can be strengthened $[\mathrm{x}(\mathrm{b})=$ $4,65]$. The medium effect size $(d=0,49)$ illustrate that the owners and managers of travel agencies would prefer that the internal marketing initiatives which are necessary to gain the support of employees for the creation of an internal climate be better implemented.
In addition, the management of travel agencies are also aware that the success of an internal marketing strategy will be determined by the level of support received from employees. They also realise that the creation and establishment of open communication channels with employees is a prerequisite for the successful implementation of internal marketing initiatives.

\section{- Motivation of employees}

The owners and managers of travel agencies $(n=61)$ are of the opinion that their current application of the techniques to motivate employees to deliver a better performance is good $[x(\mathrm{a})=3.80]$. However, the owners or managers view the ideal application of these techniques higher $[x(b)=4.49]$. The large effect size $(\mathrm{d}=0,85)$ illustrate that the owners and managers of travel agencies holds the view that the motivation of employees must be a priority to ensure an increase in their performance levels.

\section{- Building blocks of internal marketing}

The owners and managers of travel agencies $(n=61)$ view their current application of the principles which are conducive for the creation of an internal marketing climate as good $[x(\mathrm{a})=4.02]$. However, these owners or managers are of the opinion that the ideal application of these principles should be higher $[x(b)=4.59]$. The medium effect size $(d=0,70)$ illustrate that the owners and managers of travel agencies would prefer that the principles which are conducive for the establishment of an internal marketing environment be better implemented.

\section{- Internal marketing research areas}

The owners and managers of travel agencies $(n=61)$ indicated that their current application of research activities to determine the internal needs of employees are good $[x(a)=3,91]$. These owners or managers are, however, of the opinion that the ideal application of these research activities should be higher $[x(b)=4,49]$. The medium effect size $(d=0,74)$ illustrate that the owners and managers of travel agencies would prefer that research activities be better implemented to establish the internal needs of employees.

\section{- Implementation of internal marketing activities}

The owners and managers of travel agencies $(n=61)$ are of the opinion that the current application of their internal marketing activities are good $[x(a)=3.99]$. However, they view the ideal application of these activities higher $[x(b)=$ 4.51]. The large effect size $(d=0,80)$ illustrate that the owners and managers of travel agencies holds the view that the implementation of internal marketing activities must be a priority.

\section{Influence markets}

\section{- Focus of influence marketing activities}

The owners and managers of travel agencies $(n=61)$ view the current application of their influence marketing activities as good $[x(a)=3.55]$, but are of the opinion that the ideal application of these activities could be higher $[x(b)=4.27]$. The medium effect size $(d=0,68)$ indicate that the owners and managers of travel agencies are of the opinion that the application of their influence marketing activities must be given serious consideration. 


\section{- Influencing of the influence marketing environment}

The owners and managers of travel agencies $(n=61)$ indicate that they consider the influence which the external environment have on their daily activities $[x(a)=4.19]$. These owners or managers are, however, of the opinion that they should consider such an influence even more strongly $[x(b)=4.59]$. The medium effect size $(d=0,54)$ indicate that the owners and managers of travel agencies are of the opinion that they should consider the influence which the external environment have on their daily operations, more seriously.

\section{- Approach to influencer}

The owners and managers of travel agencies $(n=61)$ view their current approach to influencers, given specific influencing issues, as good $[x(\mathrm{a})=3.95]$, but view the ideal application thereof as higher $[x(b)=4.24]$. The medium effect size $(d=0,57)$ illustrate that the owners and managers of travel agencies would prefer that their approach to influencers, given specific influencing issues, be better planned, implemented and managed.

\section{- Reasons for the application of influence marketing activities}

The owners and managers of travel agencies $(n=61)$ view their current reasons for the application of influence marketing activities as good $[x(a)=3.40]$. However, these owners or managers view the ideal application of these influence marketing activities as higher $[x(b)=4.12]$. The medium effect size $(d=0,73)$ indicate that the owners and managers of travel agencies believe that the reasons why they apply influence marketing activities must be given serious consideration.

\section{- Lobbying activities}

The owners and managers of travel agencies $(n=61)$ view their current application of the components which are important before influence marketing activities are initiated as good $[x(\mathrm{a})=3.44]$. However, these owners or managers view the ideal application thereof as higher $[x(b)=4.09]$. The large effect size $(d=0,86)$ indicate that the owners and managers of travel agencies believe that the components which are important before influence marketing activities are initiated must be given priority.

\section{- Ground principles when applying influence marketing principles}

The owners and managers of travel agencies $(n=61)$ believe that the current application of ground principles which add value to their influence marketing activities with external role players as good $[x(a)=4.12]$, but put the ideal application thereof as higher $[x(b)=4.36]$. The medium effect size $(d=0,56)$ indicate that the owners and managers of travel agencies $(n=61)$ would prefer that the ground principles which add value to their influence marketing activities with external role players be better implemented.

\section{Managerial implications}

The managerial implications of the study is listed below and is discussed according to the different markets which is characteristic of the travel agency industry in the Western Cape province.

\section{Supplier markets}

Travel agencies and their suppliers should work in collaboration to improve their service delivery to customers by sharing information on product development, marketing and promotional strategies as well as future distribution initiatives. Special offers which suppliers such as SAA and the Protea and Southern Sun hotel groups are making directly available on the internet to customers, must also be available to travel agencies at the same price. This will install trust in the relationship which travel agencies have with these suppliers since both the provision and receipt of value is the foundation of a good relationship between parties.

The research further indicated that travel agencies should focus more on relationship building activities rather than supplier evaluation criteria when establishing a relationship with a supplier. Relationship building activities is more conveniently applied in an environment where supplier market relationships is characterised by a partnership approach. It is recommended that the management of travel agencies should rather, in the future, focus on building relationships with a small, strategic number of suppliers to ensure that value is added to the daily functioning of their businesses. This will ensure that the travel agency industry will secure long term relationships with strategic suppliers which will add positive value to their market growth, competitiveness and ability to improve on their customer satisfaction levels.

\section{Customer markets}

An environment must be created which is more accessible to the critical interaction with customers. Travel agencies must be better organised to ensure the retention of customers. It can include the establishment of a customer service office which receives, address and administratively manage all the corporate and leisure market enquiries of customers. This will ensure that the queries of customers are addressed in a professional manner which will have a positive influence on the retention of customers.

In addition, the research activities within the travel agency must be managed in a more formal manner to determine the need and satisfaction levels of customers. A larger amount of planning must be allocated to the research initiatives of the travel agency to specify its purpose and outcomes. In addition, product development and service deliverance must be more based on the needs and preferences of customers. This aspect is especially relevant to the corporate market which represents the largest percentage of the travel agencies' income. The professional management of a trusting relationship with the corporate market is therefore significant to ensure its loyalty to the travel agency in the future.

\section{Referral markets}

A stronger focus is required on the identification of positive word-of-mouth referrals which can become part of the marketing strategy of the travel agency. Information regarding the products and services of the travel agency can 
be provided to these individuals to develop their value adding to the marketing function of the travel agency further. It is for this reason that the development of influential word-of-mouth referrals are important for the travel agency. The customers of travel agencies must also be provided with products and services which are of a high quality. This will ensure that the communication of travel agency customers to the general public will motivate the latter to purchase from the travel agency. The positive referral potential of word-of-mouth referrers must be based on their experience of the products and services of the travel agency and not their expectation of it.

\section{Recruitment markets}

Travel agencies must place a larger emphasis on emotional intelligence (e.g. motivation, empathy, social skills and self image) when recruiting new candidates. The future survival of travel agencies will be determined by the task awareness of employees which is directly influenced by their emotional intelligence. The execution of a human resources audit must also become a priority function for the travel agency. This will empower the travel agency to attend to their human resources needs in advance. In addition, travel agencies must also compile a data basis of available candidates from which the travel agency can obtain a Curriculum Vitae. This will inform the travel agency of experienced and qualified individuals which can be approached for a vacant position.

Furthermore, the travel agency must be marketed as an employer which supports the personal development and growth of employees. This will empower the employee to grow within the travel agency which is seen as a working environment supportive of employee satisfaction. In addition, to recruit qualified and experienced candidates to the travel agency in the future, the latter will need to focus more on the fringe-benefit package which is offered to such a candidate. More emphasis will need to be placed on aspects such as profit sharing, a motor vehicle allowance, travel opportunities as well as skill and academic training (e.g. a short course and diplomas) in the field of tourism to recruit and retain experienced employees.

\section{Internal markets}

The owners and managers of travel agencies need to manage their employees more professionally as internal customers of the travel agency. This aspect is important since the satisfaction of employee needs is required to ensure the satisfaction of external customer needs. The professional management of employees can also strengthen their future loyalty towards the internal marketing initiatives of the travel agency. It is therefore important that the planning and development of internal products such as training, promotion, merit offerings, performance bonuses, profit sharing and the participation of employees in management decision making be done in collaboration with the employees of the travel agency.

A positive internal climate can be created to stimulate the motivation levels of employees of travel agencies in the Western Cape province. This can be achieved by focusing on the satisfaction of the individual needs of employees with regard to their working environment, working conditions and organisational benefits. The continuous research of employee satisfaction levels and training needs is also important to stimulate their motivation levels within the business.

The management of travel agencies must also improve on their level of internal communication. This will ensure the creation of an environment within the travel agency that will install mutual respect, trust and concern for the needs and wants of both management and employees. Management can furthermore make use of different mediums to improve their level of communication to employees. This encompass the use of individual discussion sessions, internal news letters as well as formal and informal information sessions to create a platform for improved communication within the travel agency. Informal information sessions can be used as an informal promotional technique to change the attitude of employees.

\section{Influence markets}

The owners and/or managers of travel agencies must improve their knowledge of influence marketing. The fast pace of transformation in the travel agency industry in South Africa requires that travel agencies must have a larger influence on the decisions taken by ASATA as the representative body of travel agencies in Southern Africa. Travel agents must also develop a broader knowledge of the different methods which are available to influence ASATA with regard to specific influence issues. Travel agencies must furthermore apply the research process more definitely when influence marketers are identified to promote the interests of the travel agency. This will ensure that individuals, professional associations, politicians and lobbyists are more easily identified to promote the interests of travel agencies on a provincial and national level.

A collective bargaining power must also be created amongst the individual travel agencies before an ASATA meeting is attended. This implies that travel agencies with a similar opinion on specific issues must share their ideas before an ASATA meeting is attended. The mindset of individuals or groups at an ASATA conference or meeting must be established before travel agencies apply their influence marketing activities on these individuals or groups Finally, a greater focus must be put on the identification of influential influencers which can promote the interests of the travel agency. A data register of the most influential influence marketers must be developed to provide the travel agency with information on them in the future when their services might be required.

\section{Conclusion}

The past decade was characterised by a comprehensive change in marketing theory which gave rise to the development of relationship marketing. Against the background of a growing need for interaction between suppliers, marketers and consumers relationship marketing is viewed as an interactive process where the building of relationships are of primary concern (Ndubisi, 2007:98-100; Yau, Lee, Chow, Sin \& Tse, 2000:1). Relationship 
marketing are characterised by the creation and establishment of a long term relationship between buyers and sellers which holds a competitive advantage for the organiation (Sin, Tse, Yau, Chow, Lee \& Lau, 2005:185).

This article provided a theoretical perspective on the different markets of relationship marketing. It was followed by a discussion on the findings of the study. These findings concluded that the relationships between travel agencies and the different role players in their market environment are fragmented. The direct marketing initiatives of SAA and hotel groups such as the Southern Sun and Protea hotels are putting strain on the current relationship between travel agencies and these suppliers. Travel agencies also do not research the needs and wants of their customers on a continuous basis to determine their preferences with regard to the supply of products and services. The large staff turnover in the travel agency industry is the result of poor salaries, a lack of educational sponsorships and poor management relationships with employees working for travel agencies.

The article concluded with a focus on the managerial implications of the findings. The major managerial implications of the study were that travel agencies and their suppliers should work in collaboration to improve their service delivery to customers by sharing information on product development, marketing and promotional strategies as well as future distribution initiatives. An environment must also be created which is more accessible to the critical interaction with customers. In addition, the customers of travel agencies must be provided with products and services which are of a high quality. This will ensure that the communication of travel agency customers to the general public will motivate the latter to purchase from the travel agency. Finally, the travel agency must also be marketed as an employer which supports the personal development and growth of employees.

\section{References}

Cant, M. 2000. 'The marketing arena'. In: Strydom, J., Jooste, C. \& Cant, M. Marketing management. Kenwyn: Juta. pp.16-18.

Cohen, J. 1988. Analysis for the behavioural sciences. $2^{\text {nd }}$ Edition. Hillsdale, N.J: Earlbaum.

Eiriz, V. \& Wilson, D. 2006. 'Research in relationship marketing: antecedents, traditions and integration', European Journal of Marketing, 40(3/4):275-291.

Ellis, S.M. \& Steyn, H.S. 2003. 'Practical significance (effect sizes) versus or in combination with statistical significance (p-values)', Managament Dynamics: Contemporary Research, 12(4):51-53.

Flood, P. \& Gibson, C. 2002. Bestuur en indiensneming Die werwing, ontwikkeling en motivering van mense. Kenilworth: Ampersand Press.

George, R. 2006. Marketing South African tourism. $2^{\text {nd }}$ Edition. Cape Town: Oxford University Press.
Grönroos, C. 2000. Service management and marketing. A customer relationship management approach. Chichester: John Wiley and Sons.

Harwood, T., Garry, T. \& Broderick, A. 2008. Relationship marketing - Perspectives, dimensions and contexts. Berskhire: McGraw-Hill.

Hendricks, M. 1998. 'Tevrede klante 'n kragtige wapen', Finansies en Tegniek, 50(9): 6 March:54-55.

Herington, C., Johnson, L.W. \& Scott, D. 2006. 'Internal relationships - Linking practitioner literature and relationship marketing theory', European Business Review, 18(5):364-381.

Hocking, J.E., Stacks, D.W. \& McDermott, S.T. 2003. Communication research. Boston: A\& B publishers.

Jordaan, Y. \& Prinsloo, M. 2004. Grasping services marketing. Pretoria: V\&R Printing Works.

Kotler, P. \& Armstrong, G. 2004. Principles of marketing. Upper Saddle River: Pearson Education.

Lamb, C.W., Hair, J.E., McDaniel, C., Boshoff, C. \& Terblanche, N.S. 2004. Marketing. Johannesburg: Oxford University Press.

Levering, A. \& Liljander, V. 2006. 'Does relationship marketing improve customer relationship satisfaction and loyalty?', International Journal of Bank Marketing, 24(4):233-251.

Mostert, K. \& Rathbone, A.D. 2007. 'Work characteristics, work-home interaction and engagement of employees in the mining industry', Management Dynamics, 16(2):36-52.

Ndubisi, N.O. 2007. 'Relationship marketing and customer loyalty', Marketing Intelligence and Planning Journal, 25(1):98-106.

Nunnally J.C. \& Bernstein, I.H. (1994). Pscychometric Theory. $3^{\text {rd }}$ Edition. New York: McGraw-Hill.

Otto, M. 2004. 'Interne bemarking by geselekteerde versekeringsondernemings'. Proefskrif vir die graad D.Phil, NWU Potchefstroom.

Parvatiyar, A. \& Sheth, J.N. 2000. 'Relationship marketing in consumer markets: Antecedents and consequences'. In Sheth, J.N. \& Parvatiyar, A. Handbook of relationship marketing. California: Sage Publications, Inc. pp. 8-12.

Payne, A., Ballantyne, D. \& Christopher, M. 2005. 'A stakeholder approach to relationship marketing strategy The development and use of the "six markets" model', European Journal of Marketing, 39(7/8):855-871.

Steyn, H.S. (Jr.) 1999. Praktiese beduidenheid: die gebruik van effekgroottes. Wetenskaplike bydraes, Reeks B: 
Natuurwetenskappe nr. 117. Publikasiebeheerkomitee, PU vir $\mathrm{CHO}$, Potchefstroom.

Steyn, T.F.J. 2000. 'Verhoudingsbemarking by geselekteerde vervaardigingsondernemings in die Noordwes Provinsie'. Potchefstroom: Proefskrif vir die graad D.Phil aan die PU vir $\mathrm{CHO}$.

Steyn, T.F.J., Ellis, S.M. \& Musika, F.A.A. 2004. 'Implementing relationship marketing: The role of internal and external customer orientation'. Paper presented at the European Institute for Advances Studies in Management (EIASM) Workshop on Relationship Marketing, Brussels, Belgium.

Schultz, H.B. 2001. 'Workforce planning and recruitment'. In: Nel, P.S. 2001. Human resources management. Cape Town: Oxford University Press, Southern Africa, pp. 218235.

Sin, L.Y.M., Tse, A.C.B., Yau, O.H.M., Chow, R.P.M., Lee, J.S.Y. \& Lau, L.B.Y. 2005. 'Relationship marketing orientation: scale development and cross-cultural validation', Journal of Business Research, 58:185-194.

Swart, C. 2003. 'Marketing, public relations and relationship marketing'. In: Rensburg, R.S. \& Cant, M. Public relations - South African perspectives. Sandown: Heinemann. p. 120.

Townes, M. 2007. Personal interview. Durbanville. (Cassette recording in possession of the author.)

Tustin, D.H., Ligthelm, A.A., Martins, J.H. \& Van Wyk, H. De J. 2005. Marketing research in practice. Pretoria: UNISA Pres.

Ward, T. \& Dagger, T.S. 2005. 'The complexity of relationship marketing for service customers', Journal of Services Marketing, 21(4):281-290.

Wiehahn, J. 2001. Introduction to public relations in the South African context. Cape Town: Imaging Data Solutions.

Yau, H.M., Lee, J.S.Y., Chow, R. P.M., Sin, L.Y.N. \& Tse, A.C.B. 2000. 'Relationship marketing the Chinese way', Business Horizons’, January-February:16-24.

Zampetakis, L.A. \& Moustakis, V. 2007. 'Fostering corporate entrepreneurship through internal marketing', European Journal of Innovation Management, 10(4):413433. 